\title{
IL1RN wt Allele
}

National Cancer Institute

\section{Source}

National Cancer Institute. IL1RN wt Allele. NCI Thesaurus. Code C98165.

Human IL1RN wild-type allele is located in the vicinity of 2 q14.2 and is approximately 27 $\mathrm{kb}$ in length. This allele, which encodes interleukin-1 receptor antagonist protein, plays a role in the regulation of interleukin-1-mediated signal transduction. Mutation or polymorphism of the gene is associated with susceptibility to microvascular complications of diabetes type 4, interleukin 1 receptor antagonist deficiency, increased risk of osteoporotic fractures and gastric cancer 